\title{
Camu-camu (Myrciaria dubia) and jambolan (Syzygium cumini) juice blend: sensory analysis and bioactive compounds stability
}

\author{
Ana Paula Rocha CAMPOS ${ }^{1}$, Renan Campos CHISTÉ ${ }^{1,2}$, Rosinelson da Silva PENA ${ }^{1,2 *}$ (D)
}

\begin{abstract}
In this study, the stability of the bioactive compounds from camu-camu and jambolan mixture was evaluated, and a juice blend formulation based on its sensorial properties was established. The stability of three juice formulations with camu-camu/jambolan/ water (w:w:w), 37.5:12.5:50 (JB); 37.5:0:62.5 (CJ) and 0:12.5:87.5 (JJ) was evaluated. Additionally, the bioactive compounds and sensory acceptance were performed in six juice formulations with camu-camu/jambolan: 12.5:37.5 (F1); $17.5: 32.5$ (F2); $22.5: 27.5$ (F3); 27.5:22.5 (F4); 32.5:17.5 (F5) and 37.5:12.5 (F6). The stability of the anthocyanins in the JB formulation was ensured for 5 days of storage at $25^{\circ} \mathrm{C}$. First-order reaction kinetics described the degradation of anthocyanins during 10 days of storage. The internal preference map analysis evidenced two groups: one formed by the formulations F1 and F2 and the other by F3, F4, F5 and F6. Sensory analysis showed that the formulation with the lowest concentration of camu-camu (F1) presented the highest sensory acceptance rate (80.4\%), high bioactive compounds contents: $23.04 \mathrm{mg}$ anthocyanins. $100 \mathrm{~mL}^{-1}, 353.32 \mathrm{mg}$ ascorbic acid.100 mL $\mathrm{mL}^{-1}, 892.06 \mathrm{mg}$ phenolic compounds. $100 \mathrm{~mL}^{-1}$, and high antioxidant capacity $\left(3667.78 \mathrm{mM} \mathrm{ET.100} \mathrm{mL}^{-1}\right)$. The results shows that juice blend with camu-camu/jambolan 12.5:37.5 (F1) have a good acceptance and high bioactive compounds content.
\end{abstract}

Keywords: ascorbic acid; anthocyanin; phenolic compounds; preference map.

Practical Application: Develop a camu-camu and jambolan juice blend as a promising source of bioactive compounds, with high antioxidant capacity and sensory acceptance.

\section{Introduction}

Fruit juices are consumed and appreciated all over the world, not only by their flavor but also due to the presence of macro and micronutrients, such as carbohydrates, carotenoids, vitamins, minerals, among other compounds of biological importance. Fruit juice blends have been inserted in the market as an alternative for the development of new flavors and for enabling the enrichment of the nutritional and functional value of the product; thus it enables the elaboration of beverages with beneficial health effects (Bamidele \& Fasogbon, 2017).

The elaboration of fruit juice blends allow the creation of new products, with characteristics that can be defined according to the profile of the consumer (Bhardwaj \& Pandey, 2011). In this sense, products with high levels of certain nutrients can be obtained, with specific colors, or different flavors and aromas. In the development of these new products, sensory analysis can be seen as an important tool (Palczak et al., 2019). According to $\mathrm{Yu}$ et al. (2018), the use of human senses is an important tool to determine the sensorial quality, to verify the best formulation, to evaluate the perception and the human reaction to food attributes, in order to evaluate the acceptability of the product, by the consumer.

The Amazon is the largest biodiversity reserve in the world, which includes a large number of native and exotic sub-exploited species with great nutritional potential (Oliveira et al., 2012). The search for healthy foods increased the interest for the
Amazonian fruits properties, generally rich in phenolic compounds, carotenoids, ascorbic acid and other bioactive compounds. The study of these fruits may lead to the discovery of new sources of products with high nutritional quality and contribute to the sustainable development within this region (Mariutti et al., 2014).

Camu-camu (Myrciaria dubbia) is one of the native fruit of the Amazon region. It is cultivated on the banks of rivers, lakes and streams and is recognized as the fruit with one of the highest levels of ascorbic acid, which can reach $6000 \mathrm{mg} .100 \mathrm{~g}^{-1}$ of the fruit (Neves et al., 2015). Due to the high ascorbic acid content and the presence of other compounds of interest, camu-camu has been presented as a promising source of bioactive compounds and can be used as a food with functional appeal (Chirinos et al., 2010).

Jambolan (Syzygium cumini Lamarck), in turn, is a fruit that has a single seed, wrapped by a fleshy and edible pulp, with sweet flavor and purple color. This fruit is considered an important source of anthocyanins, whose content can vary from 211 to $230 \mathrm{mg} .100 \mathrm{~g}^{-1}$ of fruit (Faria et al., 2011). Among the anthocyanins most commonly found in foods, delphinidine, petunidine and malvidin were found in larger quantities in jambolan, while cyanidin and peonidine were found in smaller amounts (Tavares et al., 2016). 
The stability of anthocyanins can be affected by the interaction with ascorbic acid (AA), oxygen, light, temperature, enzymes and metals (Cavalcanti et al., 2011). The presence of AA has shown a negative impact on the stability of anthocyanin, and the degradation mechanism consists of the direct condensation of AA with the anthocyanin molecule leading to the mutual loss of these compounds (Nikkhah et al., 2010). On the other hand, the loss of anthocyanin color in the presence of AA can occur due to oxidative cleavage of the pyrylium ring by a free radical mechanism, in which AA acts as a molecular oxygen activator and produces free radicals (Farr \& Giusti, 2018). In addition, the presence of flavonol exerts a protective effect against the degradation of anthocyanins, in the presence of AA, probably by competing with anthocyanins in the preference for condensation reactions (Cavalcanti et al., 2011).

Based on the consumer's demand, the innovation potential and the health benefits, some factors should be considered in the development of new functional beverages, such as the identification and quantification of promising bioactive compounds, the standardization of bioactive compounds, the application of natural preservatives, the development and validation of methods to improve and ensure levels of bioactive compounds in fresh and processed products and the effects of processing on the stability of bioactive compounds (Corbo et al., 2014).

The growth of the fruit juice market in recent years, due to the demand for healthier and natural foods; the search for more exotic flavors; the relevance of camu-camu as a source of ascorbic acid and the important anthocyanins content in the jambolan have motivated this research. Thus, the aim of this study was to evaluate the stability of ascorbic acid and anthocyanins in the mixture of camu-camu with jambolan, as well as to define the most acceptable formulation for a juice blend with camu-camu and jambolan based on sensorial and functional properties of the product.

\section{Material and methods}

\subsection{Material}

The fruits of jambolan and camu-camu (40kg) were collected in Santarém Novo (Pará, Brazil) (0055'44" S and 47²3'49” W) and Moju (Pará, Brazil) (0153'02” S and 4846’08” W), respectively. The fruits were collected in November and December 2017. The fruits were stored in isothermic container and transported to the Federal University of Pará (Belém, Pará, Brazil) (01²7’21" $S$ and $\left.48^{\circ} 30^{\prime} 16^{\prime \prime} \mathrm{W}\right)$. In the laboratory, the fruits were selected and submitted to sanitization in a sodium hypochlorite solution (100 mg. $\mathrm{L}^{-1}$ ) for $5 \mathrm{~min}$, followed by washing in distilled water. The fruits were packed in $1 \mathrm{~kg}$ polyethylene bags, wrapped in aluminum foil for light protection, and frozen at $-18^{\circ} \mathrm{C}$ and stored until analysis.

\subsection{Bioactive compounds determination of the fruits and blends}

The total phenolic compounds were determined according to the method proposed by Singleton \& Rossi (1965) and modified by Georgé et al. (2005). Concentrations between 20 to $100 \mathrm{mg} . \mathrm{L}^{-1}$ gallic acid were used for the external standard curve and total phenolic content was expressed as gallic acid equivalent (GAE) in mg.100 $\mathrm{mL}^{-1}$ of the sample (wet basis - wb).

The monomeric anthocyanins were determined by the differential $\mathrm{pH}$ method proposed by Giusti \& Wrolstad (2001). pH 1.0 and 4.5 buffer solutions and wavelengths of 514 and $700 \mathrm{~nm}$ were used. The results were expressed as $\mathrm{mg}$ of cyanidin 3-glucoside per $100 \mathrm{~mL}$ of the sample (wb).

The ascorbic acid content was determined by HPLC, according to the method proposed by Almeida et al. (2012), where $25 \mu \mathrm{L}$ of the sample was eluted in a $\mathrm{C}_{18}$ column with an isocratic mobile phase consisting of a sulfuric acid solution $(0.001 \mathrm{M}$, $\mathrm{pH}$ 2.5), $0.7 \mathrm{~mL} \cdot \mathrm{min}^{-1}$ flow rate, column temperature at $25^{\circ} \mathrm{C}$ and detected by diode array detector (DAD) at $245 \mathrm{~nm}$. The quantification was carried out by comparison with ascorbic acid external standard at concentrations from 1.56 to $100 \mu \mathrm{g} \cdot \mathrm{mL}^{-1}$. The ascorbic acid content were expressed as mg ascorbic acid per $100 \mathrm{~mL}$ of the sample (wb). This analyze was also performed in triplicate.

\subsection{Antioxidant capacity determination of the fruits and blends}

The antioxidant capacity was determined by the ABTS method proposed by Re et al. (1999). The ABTS ${ }^{\bullet+}$ radical was prepared from the reaction of $14 \mathrm{mM}$ ABTS with $4.9 \mathrm{mM}$ potassium persulfate $(1: 1, \mathrm{v} / \mathrm{v})$, incubated in the dark for $16 \mathrm{~h}$. Concentrations between 0.3 to $1.5 \mathrm{mM}$ of trolox were used for the external analytical curve and the antioxidant capacity was expressed as $\mathrm{mM}$ trolox equivalent (TE) per $\mathrm{mL}$ of juice (wb). The analysis was performed in triplicate.

\subsection{Stability of anthocyanins and ascorbic acid}

To evaluate the stability of anthocyanins and ascorbic acid in camu-camu and jambolan, as well as in the mixture of these two fruits, three juice formulations were prepared: CJ - juice with $37.5 \%$ camu-camu pulp and $62.5 \%$ water; JJ - juice with $12.5 \%$ jambolan pulp and $87.5 \%$ water; and JB - juice blend with $37.5 \%$ camu-camu pulp, $12.5 \%$ jambolan pulp and $50 \%$ water. In the juice blend formulation, a 3:1 ratio of camu-camu and jambolan was used as the extreme condition to evaluate the effect of the ascorbic acid of camu-camu on the degradation of the anthocyanins of jambolan. For a better comparison, in the formulation of the camu-camu and jambolan juices, the same proportions of pulp in the juice blend were used. To obtain the pulps, the fruits were thawed at $5^{\circ} \mathrm{C}$ and pulped manually. After homogenization in a processor, the pulps were passed through a sieve with mesh with a mean diameter of $0.7 \mathrm{~mm}$ to eliminate larger particle sizes.

The stability of ascorbic acid and anthocyanins in the juice formulations were evaluated during 10 days of storage in a B.O.D. chamber (Quimis, Q315M16, Brazil) at $25^{\circ} \mathrm{C}\left( \pm 1^{\circ} \mathrm{C}\right)$. The samples were stored in a high-density polyethylene (HPDE) tubes with $20 \mathrm{~mL}$ capacity, which were wrapped in aluminum foil for light protection. The sample collection for the determination of ascorbic acid and anthocyanin contents was carried out at every 24 hours. 
The degradation kinetic during storage was determined using zero-order (Equation 1) and first-order kinetic models (Equation 2). In order to evaluate the quality of the model fits, the coefficient of determination $\left(\mathrm{R}^{2}\right)$, mean relative deviations (P) and values of residues were the statistical parameters used. The half-life time $\left(\mathrm{t}_{1 / 2}\right)$, was calculated according to Equation 3.

$C=C_{0}-k t$

$C=C_{0} \exp ^{-k t}$

$t_{1 / 2}=\frac{\ln 2}{k}$

\subsection{Sensory evaluation of juice blends}

For the sensorial evaluation, six formulations of the mixed juice of camu-camu and jambolan were elaborated (Table 1). The amount of water added in all the formulations was defined experimentally, based on the juice's consistency, in comparison with commercial products of the same category. In all formulations, it was added sugar (sucrose) to obtain a product with $14^{\circ}$ Brix. For a better homogenization, the blends were passed through a colloidal mill (56-RC-6332, São Paulo, Brazil) for two minutes, and filtered in a sieve with mesh with a mean diameter of $0.7 \mathrm{~mm}$. The formulations were conditioned in polyethylene bottles, sealed and kept under refrigeration $\left(\approx 10^{\circ} \mathrm{C}\right)$, until the sensory test.

The acceptance test with a hedonic scale of nine points was used, in which the following attributes were evaluated: color, aroma, flavor and overall impression (Stone \& Sidel, 2004). Thirty $\mathrm{mL}$ of the sample was served at $10^{\circ} \mathrm{C}\left( \pm 3^{\circ} \mathrm{C}\right)$ in plastic cups, coded with three random digits. The analysis was performed in individual cabin, using white light for better visualization of the product, in two sessions, with 100 untrained judges from both genders, between 17 and 58 years old. Acceptability indexes above $70 \%$ were considered acceptable, as recommended by Lucas et al. (2018). The sensory analysis was approved by the Research Ethics Committee of the Federal University of Pará (CAAE 82497817.0.0000.0018).

\subsection{Statistical analysis}

The statistical analyses were performed using the software Statistica 7.0. The results of the bioactive compound analysis

Table 1. Composition of the juice blend formulations from camu-camu and jambolan.

\begin{tabular}{cccc}
\hline Formulation & $\begin{array}{c}\text { Camu-camu } \\
\text { pulp (\%) }\end{array}$ & $\begin{array}{c}\text { Jambolan pulp } \\
(\%)\end{array}$ & $\begin{array}{c}\text { Water } \\
(\%)\end{array}$ \\
\hline F1 & 12.5 & 37.5 & 50 \\
F2 & 17.5 & 32.5 & 50 \\
F3 & 22.5 & 27.5 & 50 \\
F4 & 27.5 & 22.5 & 50 \\
F5 & 32.5 & 17.5 & 50 \\
F6 & 37.5 & 12.5 & 50 \\
\hline
\end{tabular}

and the sensory acceptance test were assessed using analysis of variance (ANOVA) and Tukey's multiple comparison test ( $\mathrm{p} \leq$ 0.05). To obtain the Internal Preference Map, acceptance scores were organized into an array of products (in rows) and judges (in columns), which was submitted to Principal Component Analysis (PCA). The procedure was performed for each sensory attribute separately (color, aroma, flavor and overall impression), obtaining four preference maps. The results were expressed in dispersion graphs of the formulations and correlation of the data of each consumer with the first two main components.

\section{Results and Discussion:}

\subsection{Stability of anthocyanins and ascorbic acid}

The concentrations of anthocyanins and ascorbic acid of the juice blend (JB), camu-camu juice (CJ) and jambolan juice (JJ), during 10 days storage at $25^{\circ} \mathrm{C}$ are shown in Table 2. The concentration of anthocyanins significantly decreased in the three juices ( $\mathrm{p} \leq 0.05$ ), during the storage period. However, until the fifth day, the anthocyanins decrease was less significant, with anthocyanins retention of $91 \%$ for JB and $73 \%$ for JJ, but for CJ the decrease was more significant, with retention of $42 \%$. After the fifth day, the anthocyanins contents decrease was much more expressive, with a retention level of 55\% for JJ, 22\% for JB and $13 \%$ for CJ at ten days of storage. The results showed that in five days of storage, the retention of anthocyanins was higher in JB than in JJ, but at ten days of storage, the retention in JB was less than half observed in JJ. This behavior can be attributed to the presence of tannins in the jambolan (Tavares et al., 2016) and camu-camu fruits (Kaneshima et al., 2016).

The stability of anthocyanins is affected by the direct condensation reaction of tannins and anthocyanins, where they act as nucleophiles and electrophiles, to form anthocyanin-tannin adducts and tannin-anthocyanin adducts or by the acetaldehyde mediated condensation that links anthocyanin and tannin by an ethyl bridge. These reactions produce a variety of structures, including pigmented and colorless species, which can interfere with the levels of monomeric anthocyanins (Türkyılmaz \& Özkan, 2014). On the other hand, the retention of the anthocyanins observed for JB until the fifth day of storage, may be associated with the flavonoids present in the blend (Branco et al., 2016), which may protect the anthocyanins by intermolecular copigmentation, due to the decrease in the production of pseudobase carbinol and the increase of quinoidal base stabilization (Cavalcanti et al., 2011).

The degradation of anthocyanins in the juice blend showed a good correlation with the first order reaction kinetics (Table 3 ), according to the high coefficient of determination $\left(\mathrm{R}^{2}\right)$ and low mean relative deviation $(\mathrm{P})$ value, and residue with random distribution. These parameters enable the use of first-order reaction to predict anthocyanins degradation, and the juice blend presented a half-life time of 3.8 days.

The ascorbic acid concentration presented significant variations ( $\mathrm{p} \leq 0.05$ ) during the storage (Table 2 ), but the reduction more representative was for JJ. The results show that there was not degradation of ascorbic acid in JB, after ten days of storage; when the retention levels were of $94 \%$ for 
Table 2. Stability of anthocyanins for 10 days storage at $25^{\circ} \mathrm{C}$.

\begin{tabular}{|c|c|c|c|c|c|c|}
\hline \multirow{2}{*}{$\begin{array}{l}\text { Time } \\
\text { (days) }\end{array}$} & \multicolumn{3}{|c|}{ Anthocyanins (mg.100 mL $\mathrm{m}^{-1}$ ) } & \multicolumn{3}{|c|}{ Ascorbic acid (mg.100 mL $\left.\mathrm{m}^{-1}\right)$} \\
\hline & $\mathrm{JB}$ & CJ & $\mathrm{JJ}$ & $\mathrm{JB}$ & CJ & $\mathrm{JJ}$ \\
\hline 1 & $10.57 \pm 0.01^{\mathrm{a}}$ & $0.86 \pm 0.04^{\mathrm{a}}$ & $15.61 \pm<0.01^{\mathrm{a}}$ & $1031.9 \pm 0.3^{\mathrm{e}}$ & $1099.5 \pm 0.3^{\text {de }}$ & $0.66 \pm 0.04^{\mathrm{a}}$ \\
\hline 3 & $8.3 \pm 0.5^{\mathrm{cd}}$ & $0.51 \pm 0.01^{\mathrm{ab}}$ & $9.1 \pm 0.5^{\mathrm{cd}}$ & $1201.6 \pm 0.2^{\mathrm{bc}}$ & $1277.1 \pm 0.5^{\mathrm{bc}}$ & $0.27 \pm 0.03^{\text {ef }}$ \\
\hline 4 & $7.64 \pm 0.04^{\mathrm{d}}$ & $0.50 \pm<0.01^{\mathrm{ab}}$ & $8.77 \pm 0.07^{\mathrm{cd}}$ & $1162.2 \pm 0.2^{\mathrm{cd}}$ & $1137.9 \pm 0.6^{\mathrm{e}}$ & $0.29 \pm 0.01^{\mathrm{de}}$ \\
\hline 6 & $5.3 \pm 0.2^{\mathrm{e}}$ & $0.3 \pm 0.3^{\mathrm{b}}$ & $10.2 \pm 0.8^{\mathrm{bc}}$ & $1273.6 \pm 0.2^{\mathrm{b}}$ & $1637.5 \pm 0.3^{\mathrm{a}}$ & $0.40 \pm 0.08^{c}$ \\
\hline 7 & $3.1 \pm 0.2^{\mathrm{f}}$ & $0.17 \pm<0.01^{b}$ & $10.2 \pm 0.3^{\mathrm{bc}}$ & $1385.7 \pm 0.4^{\mathrm{a}}$ & $1330.1 \pm 0.3^{\mathrm{b}}$ & $0.33 \pm 0.06^{\mathrm{d}}$ \\
\hline 8 & $3.3 \pm 0.1^{\mathrm{f}}$ & $0.10 \pm 0.08^{\mathrm{b}}$ & $8.2 \pm 0.2^{\mathrm{d}}$ & $1221.04 \pm 0.43^{b c}$ & $1221.29 \pm 0.02^{\mathrm{bcd}}$ & $0.28 \pm 0.02^{\text {ef }}$ \\
\hline 9 & $2.7 \pm 0.1^{\mathrm{f}}$ & $0.17 \pm 0.05^{\mathrm{b}}$ & $9.0 \pm 0.4^{\mathrm{cd}}$ & $1054.3 \pm 0.2^{\mathrm{e}}$ & $1341.59 \pm 0.06^{\mathrm{b}}$ & $0.28 \pm 0.05^{\mathrm{ec}}$ \\
\hline
\end{tabular}

Mean followed by the same letter in the column did not differ statistically ( $\mathrm{p}>0.05$ ). JB - juice blend with $37.5 \%$ camu-camu pulp, $12.5 \%$ jambolan pulp and $50 \%$ water; CJ - juice with $37.5 \%$ camu-camu pulp and $62.5 \%$ water; JJ - juice with $12.5 \%$ pulp of jambolan and $87.5 \%$ of water.

Table 3. Kinetic model parameters for anthocyanin degradation reactions of juice blend.

\begin{tabular}{ccc}
\hline \multirow{2}{*}{ Parameters } & \multicolumn{2}{c}{ Kinetic order } \\
\cline { 2 - 3 } & Order zero & First order \\
\hline $\mathrm{k}$ & 0.979 & 0.182 \\
$\mathrm{R}^{2}$ & 0.864 & 0.882 \\
$\mathrm{P}$ & 13.81 & 7.74 \\
Residue analysis & $\mathrm{B}$ & $\mathrm{R}$ \\
\hline
\end{tabular}

$\mathrm{k}$ - Rate constant; B - Biased; R - Random.

CJ and 38\% for JJ. The observed behavior suggested a high stability of ascorbic acid in the presence of anthocyanins and that ascorbic acid was not the responsible for the decrease of anthocyanins in juice blend. The $\mathrm{pH}$ may influence the stability of ascorbic acid, because this compound is well preserved in acidic solutions. In general, acid $\mathrm{pH}(\approx 2)$ is indicated for sample preparation, ensuring stability and recovery of ascorbic acid (Spínola et al., 2013). The retention observed in JB may be related to the time and temperature of storage, since the stability of ascorbic acid is maintained at temperature up to $30^{\circ} \mathrm{C}$ (Cunha et al., 2014). Maeda et al. (2007) not observed significant decrease on the ascorbic acid content during camu-camu nectar storage for 30 days at $26^{\circ} \mathrm{C}$, in the absence of light. According to the results, it can be stated that a $\mathrm{pH}$ of 2.8 , storage time of 10 days and temperature of $25^{\circ} \mathrm{C}$ were not sufficient to promote significant changes in the concentration of ascorbic acid in juice blend studied.

\subsection{Functional characterization of juice blend}

Table 4 shows the concentrations of bioactive compounds and antioxidant capacity for the six formulations of camu-camu and jambolan juice blends. In relation to the pulp composition, with the increase of proportion of camu-camu in formulation, it were observed the increase of the ascorbic acid and decrease of anthocyanin contents. Additionally, it was observed an increase in the concentration of total phenolic compounds and in the antioxidant capacity with the increase of camu-camu in juice blends.

The formulations F1 and F2 did not present differences $(p>0.05)$ for the anthocyanins content, which are responsible for the violet color in the juice blend. However, the content of anthocyanins in the formulation F6 represents $39.6 \%$ of the content observed in F1. Lower anthocyanins contents were reported for camu-camu juice (2.51 mg.100 $\left.\mathrm{mL}^{-1}\right)$ (Maeda et al., 2006) and for eight grape juice samples $\left(0.2\right.$ to $\left.6.7 \mathrm{mg} .100 \mathrm{~mL}^{-1}\right)$ (Malacrida \& Motta, 2005).

The formulation F1 represents $29.4 \%, 20 \%$ and $43.5 \%$ of the ascorbic acid and phenolic compounds contents, and antioxidant capacity, respectively, of the amounts observed in formulation F6. Ascorbic acid content was similar to that found for camu-camu juice (382.07 mg.100 mL-1) (Maeda et al., 2006), and higher than that reported for tropical cashew juice $\left(223.96 \mathrm{mg} .100 \mathrm{~mL}^{-1}\right)$ (Vieira et al., 2011). Lower phenolic compounds content was found for cashew juice (182.96 mg GAE.100 mL ${ }^{-1}$ ) (Carvalho et al., 2011). It was observed that ascorbic acid of the camu-camu pulp presented a greater contribution to the high antioxidant capacity of the juice blend. The antioxidant capacity of the formulations was similar to the reported for aronia juice (5433 mM ET. $100 \mathrm{~mL}^{-1}$ ) (Błaszczak et al., 2017), and above that found for cashew juice (7.4 mM ET.100 $\mathrm{mL}^{-1}$ ) (Carvalho et al., 2011). According to the data reported in the literature, all the formulations of juice blend from camu-camu and jambolan can be considered as promising sources of bioactive compounds with high antioxidant capacity.

\subsection{Sensory analysis of juice blend}

The acceptance indexes (AI) values of the juice blend formulations from camu-camu and jambolan are presented in Table 5, for each sensorial attribute evaluated. It was observed a significant decrease $(\mathrm{p} \leq 0.05)$ in the AI for the color and flavor attributes, with the increase of the camu-camu pulp concentration in the formulations. However, for the color attribute, there was 
Table 4. Anthocyanin, ascorbic acid and phenolic compounds contents, and antioxidant capacity (ABTS) of the juice blend of camu-camu and jambolan.

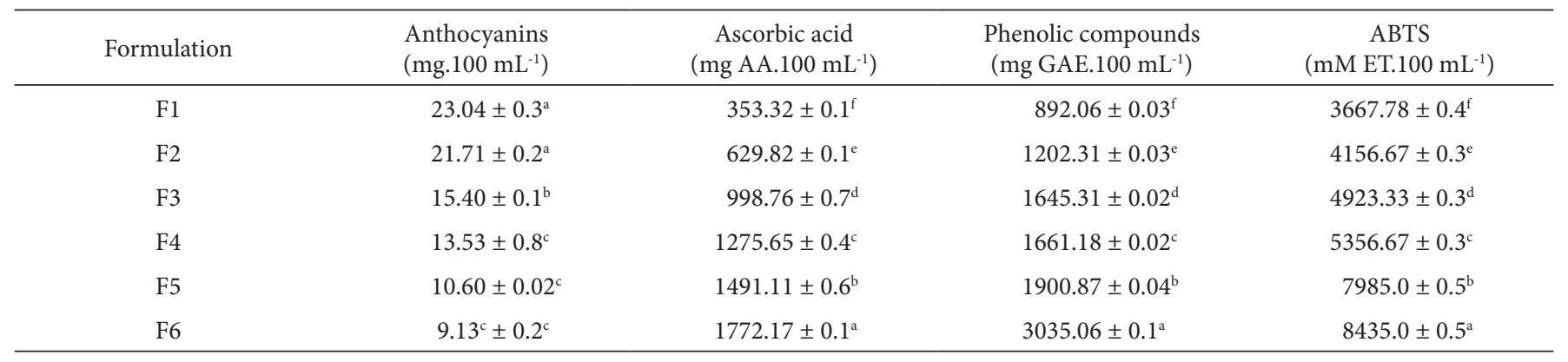

Mean followed by the same letter in the column did not differ statistically ( $\mathrm{p}>0.05$ ). GAE - Gallic Acid Equivalent; ET - Equivalent Trolox; F1 - juice blend with 12.5\% of camu-camu pulp and $37.5 \%$ of jambolan pulp; F2 - juice blend with $17.5 \%$ camu-camu pulp and $32.5 \%$ jambolan pulp; F3 - juice blend with $22.5 \%$ of camu-camu pulp and $27.5 \%$ of jambolan pulp; F4 - juice blend with $27.5 \%$ camu-camu pulp and $22.5 \%$ jambolan pulp; F5 - juice blend with $32.5 \%$ of camu-camu pulp and $17.5 \%$ of jambolan pulp; F6 - juice blend with $37.5 \%$ camu-camu pulp and $12.5 \%$ jambolan pulp.

Table 5. Acceptance index of the sensory attributes of the mixed juice formulations of camu-camu and jambolan.

\begin{tabular}{ccccc}
\hline Formulation & Color & Flavor & Aroma & Overall impression \\
\hline F1 & $90.8^{\mathrm{a}}$ & $76.3^{\mathrm{a}}$ & $69.2^{\mathrm{a}}$ & $80.4^{\mathrm{a}}$ \\
F2 & $88.7^{\mathrm{a}}$ & $69.7^{\mathrm{ab}}$ & $68.0^{\mathrm{a}}$ & $75.6^{\mathrm{a}}$ \\
F3 & $88.4^{\mathrm{a}}$ & $65.8^{\mathrm{bc}}$ & $68.2^{\mathrm{a}}$ & $67.8^{\mathrm{b}}$ \\
F4 & $86.3^{\mathrm{ab}}$ & $60.6^{\mathrm{cd}}$ & $66.0^{\mathrm{a}}$ & $65.1^{\mathrm{bc}}$ \\
F5 & $82.3^{\mathrm{bc}}$ & $56.2^{\mathrm{d}}$ & $64.7^{\mathrm{a}}$ & $64.9^{\mathrm{bc}}$ \\
F6 & $77.7^{\mathrm{c}}$ & $53.7^{\mathrm{d}}$ & $66.1^{\mathrm{a}}$ & $59.9^{\mathrm{c}}$ \\
\hline
\end{tabular}

Mean followed by the same letter in the column did not differ statistically (p > 0.05). F1 - juice blend with $12.5 \%$ of camu-camu pulp and $37.5 \%$ of jambolan pulp; F2 - juice blend with $17.5 \%$ camu-camu pulp and $32.5 \%$ jambolan pulp; F3 - juice blend with $22.5 \%$ of camu-camu pulp and $27.5 \%$ of jambolan pulp; F4 - juice blend with $27.5 \%$ camu-camu pulp and $22.5 \%$ jambolan pulp; F5 - juice blend with 32.5\% of camu-camu pulp and 17.5\% of jambolan pulp; F6 - juice blend with 37.5\% camu-camu pulp and $12.5 \%$ jambolan pulp.

no statistical difference between the formulations F1 to F4 and the flavor attribute did not present differences between the formulations F1 and F2; although the formulation F1 presented the highest mean value for this attribute. For the aroma, the observed variations were not statistically significant $(p>0.05)$. The analysis of these sensorial attributes is important to determine the quality and acceptability of the final product (Yu et al., 2018).

According to the sensory test, the color, flavor and aroma attributes presented the same trend, being the highest acceptance index (AI) obtained for the formulations F1 (12.5\% camu-camu and $37.5 \%$ jambolan) and F2 (17.5\% of camu-camu and $32.5 \%$ of jambolan). The AI for the overall impression of these formulations was over $70 \%$, which is considered satisfactory for the sensory acceptance of a food product (Lucas et al., 2018).

The Figure 1 shows the internal preference maps generated for the acceptance data of the six formulations of the juice blend, for the attributes. For this statistical analysis, to explain the relationship of acceptance data of a product is necessary that the sum of the two main components must be at least $70 \%$ (Minim, 2013). The spatial separation of the formulations suggests the existence of groups, according to their acceptance, in all attributes analyzed.

For the color attribute (Figure 1A), the first and second main component explain $72.2 \%$ of the acceptance variability among the formulations. The spatial separation of the samples shows the formation of two groups, being a group formed by the formulations F1 and F2, with the lowest concentrations of camu-camu and larger of jambolan, and the other group formed by the other formulations (F3-F6). The preference for the formulations F1 and F2 is attribute to the intensity of the violet coloration of the juice blend, due to the presence of the anthocyanins of the jambolan, in higher concentrations in these formulations (Table 1).

For flavor and aroma attributes (Figure $1 \mathrm{~B}$ and $1 \mathrm{C}$ ), the first and second main component explain $74.8 \%$ and $79.7 \%$ of the variability of the data, respectively. Also for these attributes, the formation of a group with F1 and F2 confirms that these formulations are not statistically different ( $p>0.05)$, but are different from the other formulations. The highest concentrations of camu-camu in the formulations F3 to F6 influenced negatively the acceptance of the juice blend, for the flavor attribute, which can be attributed to the accentuated acidity of the product due to the increase in the concentration of ascorbic acid. Although the data of the Table 5 indicate no significant difference $(\mathrm{p}>0.05)$ between the formulations, for the aroma attribute, the preference map showed the formation of two groups, separating F1 and F2 from the other formulations. This behavior can be attributed to the presence of volatile compounds in juices, as $\alpha$-pinene in camu-camu (Quijano \& Pino, 2007) and trans- $\beta$-ocimene in jambolan (Mehta et al., 2017).

For overall impression (Figure 1D), which expresses the set of evaluated attributes, the first and second main components 

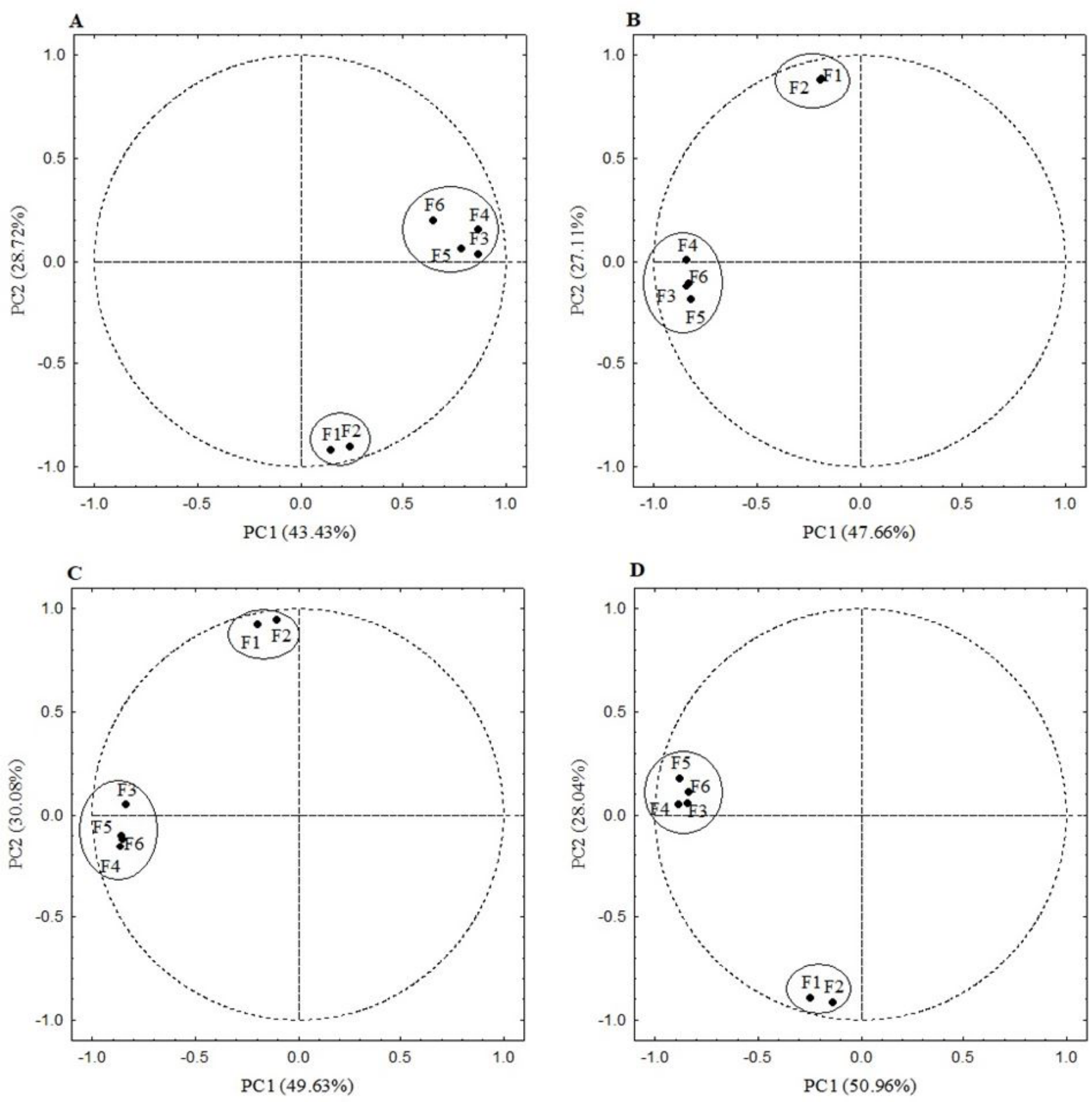

Figure 1. Graphic representation of the consumers and juice blend formulations from camu-camu and jambolan, for color (A), flavor (B), aroma (C) and overall impression (D) attributes.

explain $79 \%$ of the variability of the responses. In this case, it was also observed the formation of two groups of judges, one group with F1 and F2 and another group with the other formulations (F3-F6). Thus, a similar behavior was observed for all the evaluated attributes, as well as for overall impression: a decrease in AI of the juice blend with the increase of the camu-camu concentration in the formulation.

Vidigal et al. (2011) evaluated the sensory acceptance of açaí, camu-camu, cajá and umbu juice, and observed that the camu-camu juice obtained the lowest sensorial acceptance, due to the high acidity of the fruit. Maeda et al. (2006) attribute the restricted consumption of camu-camu to the high acidity, bitterness and astringency of the pulp. For the juice blend of camu-camu and jambolan studied, the formulations F1 and F2, which obtained the highest AI, presented the lowest ascorbic acid and phenolic compounds contents, as well as antioxidant capacity (Table 4). However, with growing search for healthier foods and the commercial viability of camu-camu and jambolan fruits, the development of juice blend with $12.5 \%$ camu-camu and $37.5 \%$ jambolan, can be considered a promising alternative for production due to the high acceptance by the judges, besides the high bioactive compounds content, mainly ascorbic acid content, promoting beneficial effects to health. 


\section{Conclusions}

The study shows that in a formulation with $37.5 \%$ camu-camu pulp, $12.5 \%$ jambolan pulp and $50 \%$ water, the stability of anthocyanins is ensured for up to five days of storage at $25^{\circ} \mathrm{C}$. The degradation of the anthocyanins of juice blend was fitted to the kinetic model of first order, with half-life time of 3.8 days. Finally, the study shows that it is possible to obtain a juice blend with $12.5 \%$ to $17.5 \%$ of camu-camu pulp, $32.5 \%$ to $37.5 \%$ of jambolan pulp and $50 \%$ of water, and $14{ }^{\circ} \mathrm{Brix}$; with high sensory acceptability and as a source of bioactive compounds with high antioxidant potential.

\section{Acknowledgements}

The authors acknowledge Conselho Nacional de Desenvolvimento Científico e Tecnológico (CNPq, Brazil) for the financial support (422739/2016-2) and Coordenação de Aperfeiçoamento de Pessoal de Nível Superior (CAPES, Brazil) for the scholarship of A. P. R. Campos (88587622234). The authors declare no conflict of interest.

\section{References}

Almeida, M., Darin, J. A., Hernandes, L., Aissa, A., Chisté, R., Mercadante, A., Antunes, L., \& Bianchi, M. (2012). Antigenotoxic effects of piquia (Caryocar villosum) in multiple rat organs. Plant Foods for Human Nutrition, 67(2), 171-177. http://dx.doi.org/10.1007/s11130-0120291-3. PMid:22562095.

Bamidele, O. P., \& Fasogbon, M. B. (2017). Chemical and antioxidant properties of snake tomato (Trichosanthes cucumerina) juice and Pineapple (Ananas comosus) juice blends and their changes during storage. Food Chemistry, 220, 184-189. http://dx.doi.org/10.1016/j. foodchem.2016.10.013. PMid:27855888.

Bhardwaj, R. L., \& Pandey, S. (2011). Juice Blends - A way of utilization of under-utilized fruits, vegetables, and spices: A review. Critical Reviews in Food Science and Nutrition, 51(6), 563-570. http://dx.doi. org/10.1080/10408391003710654. PMid:21929332.

Błaszczak, W., Amarowicz, R., \& Górecki, A. R. (2017). Antioxidant capacity, phenolic composition and microbial stability of aronia juice subjected to high hydrostatic pressure processing. Innovative Food Science \& Emerging Technologies, 39, 141-147. http://dx.doi. org/10.1016/j.ifset.2016.12.005.

Branco, I. G., Moraes, I. C. F., Argandoña, E. J. S., Madrona, G. S., Santos, C., \& Haminiuk, C. W. I. (2016). Influence of pasteurization on antioxidant and in vitro anti-proliferative effects of jambolan (Syzygium cumini (L.) Skeels) fruit pulp. Industrial Crops and Products, 89, 225-230. http://dx.doi.org/10.1016/j.indcrop.2016.04.055.

Carvalho, R. L., Miranda, M. R., \& Brasil, I. M. (2011). Evaluation of the quality, phytochemical and antioxidant activity of tropical cashew juice. Agropecuária Técnica, 32, 35-41.

Cavalcanti, R. N., Santos, D. T., \& Meireles, M. A. (2011). Non-thermal stabilization mechanisms of anthocyanins in model and food systems - An overview. Food Research International, 44(2), 499-509. http:// dx.doi.org/10.1016/j.foodres.2010.12.007.

Chirinos, R., Galarza, J., Betalleluz-Pallardel, I., Pedreschi, R., \& Campos, D. (2010). Antioxidant compounds and antioxidant capacity of Peruvian camu camu (Myrciaria dubia (H.B.K.) McVaugh) fruit at different maturity stages. Food Chemistry, 120(4), 1019-1024. http:// dx.doi.org/10.1016/j.foodchem.2009.11.041.
Corbo, M. R., Bevilacqua, A., Petruzzi, L., Casanova, F. P., \& Sinigaglia, M. (2014). Functional Beverages: The emerging side of functional food. Comprehensive Reviews in Food Science and Food Safety, 13(6), 1192-1206. http://dx.doi.org/10.1111/1541-4337.12109.

Cunha, K. D., Silva, P. R., Costa, A. L. F. S. F., \& Teodoro, A. J. (2014). Ascorbic acid stability in fresh fruit juice under different forms of storage. Brazilian Journal of Food Technology, 17(2), 139-145. http:// dx.doi.org/10.1590/bjft.2014.016.

Faria, A. F., Marques, M. C., \& Mercadante, A. Z. (2011). Identification of bioactive compounds from jambolão (Syzygium cumini) and antioxidante capacity evaluation in diferente $\mathrm{pH}$ conditions. Food Chemistry, 126(4), 1571-1578. http://dx.doi.org/10.1016/j. foodchem.2010.12.007. PMid:25213929.

Farr, J. E., \& Giusti, M. M. (2018). Investigating the interaction of ascorbic acid with anthocyanins and pyranoanthocyanins. Molecules, 23(4), 744-756. http://dx.doi.org/10.3390/molecules23040744. PMid:29570649.

Georgé, S., Brat, P., Alter, P., \& Amiot, M. J. (2005). Rapid determination of polyphenols and vitamin C in plant-derived products. Journal of Agricultural and Food Chemistry, 53(5), 1370-1373. http://dx.doi. org/10.1021/jf048396b. PMid:15740008.

Giusti, M. M., \& Wrolstad, R. E. (2001). Anthocyanins. Characterization and measurement of anthocyanins by UV-visible spectroscopy. In R. E. Wrolstad (Ed.), Current Protocols in Food Analytical Chemistry (pp. 1-13). New York: John Wiley \& Sons.

Kaneshima, T., Myoda, T. K., Nakata, M., Fujimori, T., Toeda, K., \& Nishizawa, M. (2016). Antioxidant activity of C-Glycosidic ellagitannins from the seeds and peel of camu-camu (Myrciaria dubia). Lebensmittel-Wissenschaft + Technologie, 69, 76-81. http:// dx.doi.org/10.1016/j.lwt.2016.01.024.

Lucas, B. F., De Morais, M. G., Santos, T. D., \& Costa, J. A. V. (2018). Spirulina for snack enrichment: Nutritional, physical and sensory evaluations. Lebensmittel-Wissenschaft + Technologie, 90, 270-276. http://dx.doi.org/10.1016/j.lwt.2017.12.032.

Maeda, R. N., Pantoja, L., Yuyama, L. K. O., \& Chaar, J. M. (2006). Determination of the formulation and characterization of camu-camu nectar (Myrciaria dubious McVaugh). Food Science and Technology, 26(1), 70-74. http://dx.doi.org/10.1590/S0101-20612006000100012.

Maeda, R. N., Pantoja, L., Yuyama, L. K. O., \& Chaar, J. M. (2007). Stability of ascorbic acid and anthocyanin on camu-camu (Myrciaria dubia McVaugh) nectar. Food Science and Tecnhology, 27(2), 313-316. http://dx.doi.org/10.1590/S0101-20612007000200018.

Malacrida, C. R., \& Motta, S. (2005). Total phenolic compounds and anthocyanins in grape juice. Food Science and Technology, 25(4), 659-664. http://dx.doi.org/10.1590/S0101-20612005000400006.

Mariutti, L. R. B., Rodrigues, E., Chisté, R. C., Fernandes, E., \& Mercadante, A. Z. (2014). The Amazonian fruit Byrsonima crassifolia effectively scavenges reactive oxygen and nitrogen species and protects human erythrocytes against oxidative damage. Food Research International, 64, 618-625. http://dx.doi.org/10.1016/j.foodres.2014.07.032. PMid:30011696.

Mehta, P. K., De Sousa Galvão, M., Soares, A. C., Nogueira, J. P., \& Narain, N. (2017). Volatile constituents of jambolan (Syzigium cumini L.) fruits at three maturation stages and optimization of HS-SPME GC-MS method using a central composite design. Food Analytical Methods, 11(3), 733-749. http://dx.doi.org/10.1007/s12161-017-1038-4.

Minim, V. P. R. (2013). Sensory analysis: consumer studies (3. ed.). Viçosa: Editora UFV.

Neves, L. C., Silva, V. X., Pontis, J. A., Flach, A., \& Roberto, S. R. (2015). Bioactive compounds and antioxidant activity in pre-harvest camu-camu (Myrciaria dubia (H.B.K.) Mc Vaugh) fruits. Scientia Horticulturae, 186, 223-229. http://dx.doi.org/10.1016/j.scienta.2015.02.031. 
Nikkhah, E., Khaiamy, M., Heidary, R., \& Azar, A. S. (2010). The effect of ascorbic acid and $\mathrm{H}_{2} \mathrm{O}_{2}$ treatment on the stability of anthocyanin pigments in berries. Turkish Journal of Biology, 34, 47-53. http:// dx.doi.org/10.3906/biy-0805-14.

Oliveira, V. B., Yamada, L. T., Fagg, C. W., \& Brandão, M. G. L. (2012). Native foods from Brazilian biodiversity as a source of bioactive compounds. Food Research International, 48(1), 170-179. http:// dx.doi.org/10.1016/j.foodres.2012.03.011.

Palczak, J., Blumenthal, D., Rogeaux, M. \& Delarue, J. (2019). Sensory complexity and its influence on hedonic responses: A systematic review of applications in food and beverages. Food Quality ond Preference, 71, 66-75. https://doi.org/10.1016/j.foodqual.2018.06.002.

Quijano, C. E., \& Pino, J. A. (2007). Analysis of volatile compounds of camu-camu (Myrciaria dubia (HBK) Mcvaugh) fruit isolated by different methods. The Journal of Essential Oil Research, 19(6), 527533. http://dx.doi.org/10.1080/10412905.2007.9699323.

Re, R., Pellegrini, N., Proteggente, A., Pannala, A., Yang, M., \& Riceevans, C. (1999). Antioxidant activity applying an improved ABTS radical cátion decolorization assay. Free Radical Biology \& Medicine, 26(9-10), 12311237. http://dx.doi.org/10.1016/S0891-5849(98)00315-3. PMid:10381194.

Singleton, V. L., \& Rossi, J. A. (1965). Colorimetry of total phenolics with phosphomolybdic-phosphotungstic acid reagents. American Journal of Enology and Viticulture, 16, 144-158.

Spínola, V., Mendes, B., Câmara, J. S., \& Castilho, P. C. (2013). Effect of time and temperature on vitamin $\mathrm{C}$ stability in horticultural extracts. UHPLC-PDA vs iodometric titration as analytical methods. Lebensmittel-Wissenschaft + Technologie, 50(2), 489-495. http:// dx.doi.org/10.1016/j.lwt.2012.08.020.
Stone, H., \& Sidel, J. L. (2004). Sensory evaluation practices (3rd ed.). New York: Academic Press.

Tavares, I. M. C., Lago-Vanzela, E. S., Rebello, L. P. G., Ramos, A. M., Gómez-Alonso, S., García-Romero, E., Da-Silva, R., \& HermosínGutiérrez, I. (2016). Comprehensive study of the phenolic composition of the edible parts of jambolan fruit (Syzygium cumini (L.) Skeels). Food Research International, 82, 1-13. http://dx.doi.org/10.1016/j. foodres.2016.01.014.

Türky1lmaz, M., \& Özkan, M. (2014). Effects of condensed tannins on anthocyanins and colour of authentic pomegranate (Punica granatum L.) juices. Food Chemistry, 164, 324-331. http://dx.doi. org/10.1016/j.foodchem.2014.05.048. PMid:24996341.

Vidigal, M. C. T. R., Minim, V. P. R., Carvalho, N. B., Milagres, M. P., \& Gonçalves, A. C. A. (2011). Effect of a health claim on consumer acceptance of exotic Brazilian fruit juices: Açaí (Euterpe oleracea Mart.), Camu-camu (Myrciaria dubia), Cajá (Spondias lutea L.) and Umbu (Spondias tuberosa Arruda). Food Research International, 44(7), 1988-1996. http://dx.doi.org/10.1016/j. foodres.2010.11.028.

Vieira, L. M., Sousa, M. S. B., Mancini-Filho, J., \& Lima, A. (2011). Total phenolics and "in vitro" antioxidant capacity of tropical fruit pulps. Revista Brasileira de Fruticultura, 33(3), 888-897. http:// dx.doi.org/10.1590/S0100-29452011005000099.

Yu, P., Low, M. Y., \& Zhou, W. (2018). Design of experiments and regression modelling in food flavour and sensory analysis: A review. Trends in Food Science \& Technology, 71, 202-215. http://dx.doi. org/10.1016/j.tifs.2017.11.013. 